\title{
Influence of prostaglandins on unidirectional zinc fluxes across the small intestine of the rat
}

\author{
By MOON K. SONG ${ }^{1}$, DAVID B. N. LEE AND NABEEL F. ADHAM ${ }^{2}$ \\ ${ }^{1}$ Research, and ${ }^{2}$ Medical Services, Veterans Administration Medical Center, Sepulveda, \\ CA 91343, USA, and \\ ${ }^{1}$ Department of Pediatrics and ${ }^{2}$ Department of Medicine, University of California School \\ of Medicine, Los Angeles, CA 90024, USA
}

(Received 17 August 1987 - Accepted 30 November 1987)

\begin{abstract}
1. The regulatory role of prostaglandins (PGs) $E_{2}$ and $F_{2 \alpha}$ on the zinc transport rate across the jejunal segments of rats was examined by employing the Ussing chamber technique. The $\mathrm{Zn}$ flux rate from mucosa to serosa across jejunal segments $\left(J_{\mathrm{ms}}\right)$ was 5.24 (SE 1.54) nmol/h per $\mathrm{cm}^{2}\left(n\right.$ 48) and that from serosa to mucosa $\left(J_{\mathrm{sm}}\right)$ was $15 \cdot 16$ (SE 2.38) $\mathrm{nmol} / \mathrm{h}$ per $\mathrm{cm}^{2}$ ( $n$ 48) when both sides of the segment were bathed with Ringer's bicarbonate solution containing $0.5 \mathrm{mM}$-zinc chloride and $3 \mathrm{mM}$-L-histidine.

2. When 5.0 or $50 \mu \mathrm{M}$ of either $\mathrm{PGE}_{2}$ or $\mathrm{PGF}_{2 \alpha}$ were added to the serosal side of the tissue, $J_{\text {sm }}$ generally decreased and $J_{\mathrm{ms}}$ generally increased, compared with controls. On the other hand, when $\mathrm{PGE}_{2}$ or $\mathrm{PGF}_{2 \alpha}$ was added to the mucosal side of the tissue, $J_{\mathrm{ms}}$ either did not change or increased while $J_{\mathrm{sm}}$ had a tendency to decrease.

3. The $Z_{n}$ uptake capacity of tissue increased significantly when PG was added to the serosal side of the tissuebathing medium, but not when PG was added to the mucosal side. The uptake capacity of mucosal $\mathrm{Zn}$ by jejunal segments was approximately twice that of serosal $\mathrm{Zn}$.

4. When PG was included in the tissue-bathing medium, the short-circuit current, potential difference and conductance between the mucosa- and serosa-bathing media generally decreased.

5. These results suggest that $(a)$ PGs influence $\mathrm{Zn}$ flux rate not by chelating $\mathrm{Zn}$ and carrying it across the mucosal cell membrane but by interacting with the cytosolic components, $(b)$ it is the serosal PGs which control the $\mathrm{Zn}$ flux rate and (c) PGs play a part in triggering a transduction mechanism in the intestinal $\mathrm{Zn}$ transport process.
\end{abstract}

Transport of zinc across the mucosal cells of the intestinal epithelium occurs by a series of steps (Cousins, $1979 a$ ). However, the precise mechanism has not been determined although it has been the subject of numerous investigations (Evans et al. 1975; Hurley et al. $1977 b$; Cousins, $1979 b$; Song \& Adham, 1979). It has been generally agreed that the $\mathrm{Zn}$ absorption mechanism is a facilitated diffusion process involving a carrier-mediated step (Pearson et al. 1966; Song \& Adham, 1979; Menard \& Cousins, 1983). It has been proposed that a lowmolecular-weight $\mathrm{Zn}$-binding ligand (LMW-ZBL) acts as carrier and hence as a controlling factor for Zn absorption (Evans et al. 1975; Hurley et al. 1977a; Song \& Adham, 1979). In this process, the $\mathrm{LMW}-\mathrm{ZBL}$ is presumed to chelate $\mathrm{Zn}$ at the intestinal lumen and carry it across the mucosal cells of the small intestine. However, the identity of this ligand has been controversial. Some suggested it is citrate (Hurley et al. 1977 b) and others picolinic acid (Evans \& Johnson, 1980), L-histidine (Wapnir et al. 1983) or a metallothionein metabolite (Cousins et al. 1978). We have previously demonstrated that prostoglandin (PG) $E_{2}$ chelated $\mathrm{Zn}$ and stimulated intestinal $\mathrm{Zn}$ absorption (Song \& Adham, 1978). In response to this finding, others indicated that the amount of PG in the intestinal lumen is not sufficient to control $\mathrm{Zn}$ absorption (Lonnerdal et al. 1980) or that physiological doses of $\mathrm{PGE}_{2}$ inhibited $\mathrm{Zn}$ absorption (Cousins et al. 1978). More recently, Cunnane (1982) reported that physiological doses of $\mathrm{PGE}_{2}$ inhibited absorption while pharmacological doses stimulated it. Since the half-life of PGs in the biological system is less than $1.5 \mathrm{~min}$ (Hamberg \& Samuelsson, 1971), determination of the effect of physiological doses of PGs on intestinal $\mathrm{Zn}$ transport is impossible by any conventional method, while pharmacological 
doses of PGs may produce results irrelevant to the physiological effect of PGs. It is thus necessary to examine the effect of physiological doses of PGs on $\mathrm{Zn}$ transport under conditions which ensure minimal or zero metabolism of the PGs while bathing mucosal cells. The purpose of the present study was to determine $(a)$ whether $\mathrm{PGE}_{2}$ or $\mathrm{PGF}_{2 \alpha}$ have the roles of chelators of $\mathrm{Zn}$ or of hormone-like transducers in regulating intestinal $\mathrm{Zn}$ transport, $(b)$ whether effects of PGs on intestinal $\mathrm{Zn}$ transport are dose-dependent, and (c) whether $\mathrm{PGE}_{2}$ and $\mathrm{PGF}_{2 \alpha}$ are mutually antagonistic in influencing intestinal $\mathrm{Zn}$ transport.

\section{MATERIALS AND METHODS}

Sprague-Dawley rats weighing approximately $200-250 \mathrm{~g}$ were purchased from Bentin and Kingman Inc., Fremont, CA. All animals were housed in hanging cages and were fed on an unrestricted supply of Purina rat chow and water. Animals (2-3 months old) were killed with an intravenous injection of pentobarbital $(50 \mu \mathrm{g} / \mathrm{g}$ body-weight). Sections of midjejunum were excised, rinsed free of intestinal contents with cold saline $(9 \mathrm{~g}$ sodium chloride/1), and then opened along the mesenteric border. Tissues were bathed in a solution containing $118.4 \mathrm{mM}-\mathrm{NaCl}, 4.75 \mathrm{mM}$-potassium chloride, $1.26 \mathrm{~mm}$-calcium chloride, 25.0 mM-sodium bicarbonate, $1 \cdot 19 \mathrm{mM}-\mathrm{MgSO}_{4} \cdot 7 \mathrm{H}_{2} \mathrm{O}, 1.0 \mathrm{M}$-glucose (Ringer's buffer solution), $3.0 \mathrm{~mm}$-L-histidine and $0.5 \mathrm{~mm}$-zinc chloride. The solution was gassed with oxygen-carbon dioxide $(95: 5, \mathrm{v} / \mathrm{v})$ and maintained at $37^{\circ}$ with a final $\mathrm{pH}$ of $7 \cdot 4$.

Forty-eight rats were divided into two groups of twenty-four rats. Each group of twentyfour rats was used for an experiment in which $P G$ was added either to a buffer solution containing radiolabelled $\mathrm{Zn}$ (treatment $\mathrm{A}$ ), or to a buffer solution containing only nonradioactive $\mathrm{Zn}$ (treatment $\mathrm{B}$ ). Twenty-four rats were further divided into four groups of six rats. The first group of six rats was used to determine the effect of $5.0 \mu \mathrm{M}-\mathrm{PGE}_{\mathrm{2}}$ on the ${ }^{65} \mathrm{Zn}$ flux rate across the jejunal segment compared with controls; a second group of six rats, the effect of $50 \mu \mathrm{M}-\mathrm{PGE}_{2}$; a third group of six rats, that of $5.0 \mu \mathrm{M}-\mathrm{PGF}_{2 \alpha}$; and a fourth group of six rats, that of $50 \mu \mathrm{M}-\mathrm{PGF}_{2 \alpha}$. Four segments were isolated from the mid-portion of the jejunum of each rat. The first and the fourth segments were used for the measurement of $\mathrm{Zn}$ flux in the serosa to mucosa direction and the second and the third segments for the mucosa to serosa direction. The first and the second segments were controls (no PG added) for the third and fourth segments.

Each of the four segments of mid-jejunum, taken at random, was mounted in a Lucite chamber, which permitted the exposure of defined areas of $0.67 \mathrm{~cm}^{2}$ of the mucosal and serosal surfaces to solutions which were identical in composition on both sides except for the ${ }^{65} \mathrm{Zn}$ tracer and the PGs. Each side of the chamber contained $10 \mathrm{ml}$ of the bathing Ringer's buffer solution containing $0.5 \mathrm{mM}^{-\mathrm{ZnCl}_{2}}$ and $3.0 \mathrm{~mm}-\mathrm{L}$-histidine as described previously. Short-circuit current $\left(I_{\mathrm{sc}}\right)$ and resistance of buffer solutions were measured before mounting the intestinal segments. After mounting each segment into one of the four Lucite chambers, $33 \mu \mathrm{Ci}^{65} \mathrm{Zn}$ (final specific activity $10 \mathrm{mCi} / \mathrm{mg}$ ) were added to one side of the Lucite chamber and the other side contained the same amount of non-radioactive $\mathrm{Zn}$ (0.5 mM). Since our previous experiments (Song \& Adham, 1979) showed that lumen $\mathrm{Zn}$ concentrations from 0.007 to $0.443 \mathrm{~mm}$ maintained the same rate of $\mathrm{Zn}$ absorption, we used an initial $\mathrm{Zn}$ concentration of $0.5 \mathrm{~mm}$.

$I_{\mathrm{sc}}$ was measured by a modification of the method of Ussing \& Zerahn (1951), as previously described (Lee, 1983). The spontaneous potential difference (PD) across the tissue was abolished by passing a $I_{\mathrm{sc}}$ after correction for fluid resistance using an automatic voltage clamp (Model AVC-3, Netronics, Inc., Hudson, MA). About 5 min after mounting the tissue and voltage clamping at zero $\mathrm{PD}$, a small sample $(100 \mu \mathrm{l})$ was removed from the ${ }^{65} \mathrm{Zn}$-containing reservoir for counting. Thereafter $1 \mathrm{ml}$ samples were removed from the 
opposite reservoir at $15 \mathrm{~min}$ intervals. After removal of each sample, an equal volume of Ringer's buffer solution containing $0.5 \mathrm{~mm}-\mathrm{Zn}$ and $3 \mathrm{mM}$-L-histidine was immedately added to maintain the volume. Samplings took place over a $120 \mathrm{~min}$ period. After each sampling, tissue resistance was measured. During the experimental periods, momentary opencircuiting allowed recording of the current $(I)$ required for the voltage clamp to produce an increase in PD of $10 \mathrm{mV}$. Tissue resistance was calculated as $10 \mathrm{mV} / \mathrm{I}$. Then PD of tissue was calculated from these values. In each case, the short-circuit state was immediately restored after the measurement. At the end of $120 \mathrm{~min}, 10 \mathrm{mg}$ theophylline in powder form were added to the intestinal-segment-bathing medium to determine tissue viability. The Ussing chamber was designed to circulate the tissue-bathing medium by gassing with oxygen-carbon dioxide $(95: 5, \mathrm{v} / \mathrm{v})$, and the powder form of theophylline disperses into the solution very rapidly. Theophylline stimulates chloride transport causing the PD between the two sides of the mucosal cell membrane to become more positive (Biber et al. 1986). Since the chloride transport across the cellular pathways is an active transport process, chloride flux will not occur if tissues are not viable and PD between the two sides of the mucosal membrane becomes zero.

After counting each sample in a $\gamma$-counter, $\mathrm{Zn}$ fluxes were calculated using the following equation (Lee, 1983):

$$
J_{\mathrm{ms}}=V_{\mathrm{s}}\left(P_{\mathrm{s} 2}-C P_{\mathrm{s} 1}\right) /\left(t p_{\mathrm{m}}^{*} A\right)
$$

where $J_{\mathrm{ms}}$ is the unidirectional $\mathrm{Zn}$ flux from mucosa to serosa in $\mathrm{nmol} / \mathrm{h}$ per $\mathrm{cm}^{2}, V_{\mathrm{s}}$ is the volume of medium perfusing the serosal surface $(\mathrm{ml}), P_{\mathrm{s}}$ is counts $/ \mathrm{min}$ per $\mathrm{ml}$ in the serosal reservoir, $C$ is the correction factor for dilution, $t$ is the time interval between samples 1 and $2, p_{\mathrm{n}}^{*}$ is the specific activity of ${ }^{65} \mathrm{Zn}$ in the mucosal solution in counts/min per nmol, $A$ is the area of membrane $\left(\mathrm{cm}^{2}\right)$. Before the flux values were tabulated, the resistance values for the pieces of gut used for mucosa to serosa and serosa to mucosa flux measurements were compared and these values were used to calculate net fluxes only when there was resistance matching within $30 \%$. The $\mathrm{pH}$ of all solutions was 7.4 and $\mathrm{Zn}$ concentration was $5 \times 10^{-4}$ M. According to our previous work (Song \& Adham, 1979), the concentrations of $\mathrm{PGE}_{2}$ and $\mathrm{PGF}_{2 \alpha}$ required to form an insoluble complex with $10 \mu \mathrm{g} \mathrm{Zn}$ in $1.0 \mathrm{ml}$ solution are 75 and $85 \mathrm{mM}$ respectively. Since PG concentrations in the present experiments were 5.0 and $50 \mu \mathrm{M}$, no precipitates were expected and none were observed under our experimental conditions.

The statistical evaluation was performed using Student's $t$ test. Values are presented as means with their standard errors.

\section{RESULTS}

\section{${ }^{65} \mathrm{Zn}$ flux rate when $P G E_{2}$ or $P G F_{2 \alpha}$ was added to the intestinal-segment-bathing solution containing ${ }^{65} \mathrm{Zn}$}

To examine whether physiological and pharmacological doses of $\mathrm{PGE}_{2}$ and $\mathrm{PGF}_{2 \alpha}$ influence the flux rate of $\mathrm{Zn}$ across the isolated rat intestinal segments differently, 5.0 or $50 \mu \mathrm{M}$ of either $\mathrm{PGE}_{2}$ or $\mathrm{PGF}_{2 \alpha}$, plus ${ }^{65} \mathrm{Zn}$, were added to the intestinal-segment-bathing buffer solution to measure the $\mathrm{Zn}$ flux rate. The ${ }^{65} \mathrm{Zn}$ flux rate from mucosa to serosa $\left(J_{\mathrm{ms}}\right)$ of controls was 3.26 (SE 1.09) $\mathrm{nmol} / \mathrm{h}$ per $\mathrm{cm}^{2}(n$ 24), whereas that from serosa to mucosa $\left(J_{\mathrm{sm}}\right)$ was $9.86(\mathrm{SE} 1.02) \mathrm{nmol} / \mathrm{h}$ per $\mathrm{cm}^{2}(n 24)$. As shown in Fig. 1, addition of PG almost invariably decreased the $J_{\mathrm{sm}}$ regardless of PG type, amount or side of addition. Although some of these decreases were not statistically significant, the overall decrease for the fortyeight serosa to mucosa experiments was clearly significant. When $5 \cdot 0$ or $50 \mu \mathrm{M}-\mathrm{PGE}_{2}$, or $5 \cdot 0 \mu \mathrm{M}-\mathrm{PGF}_{2 \alpha}$ were added to the serosal side of the intestinal segment, $J_{\mathrm{sm}}$ significantly decreased, while inhibition of $J_{\mathrm{sm}}$ by $50 \mu \mathrm{M}-\mathrm{PGF}_{2 \alpha}$ was not statistically significant (Fig. $1 a$ ). However, when $50 \mu \mathrm{M}-\mathrm{PGF}_{2 x}$ were added to the mucosal side, $J_{\mathrm{ms}}$ was significantly 

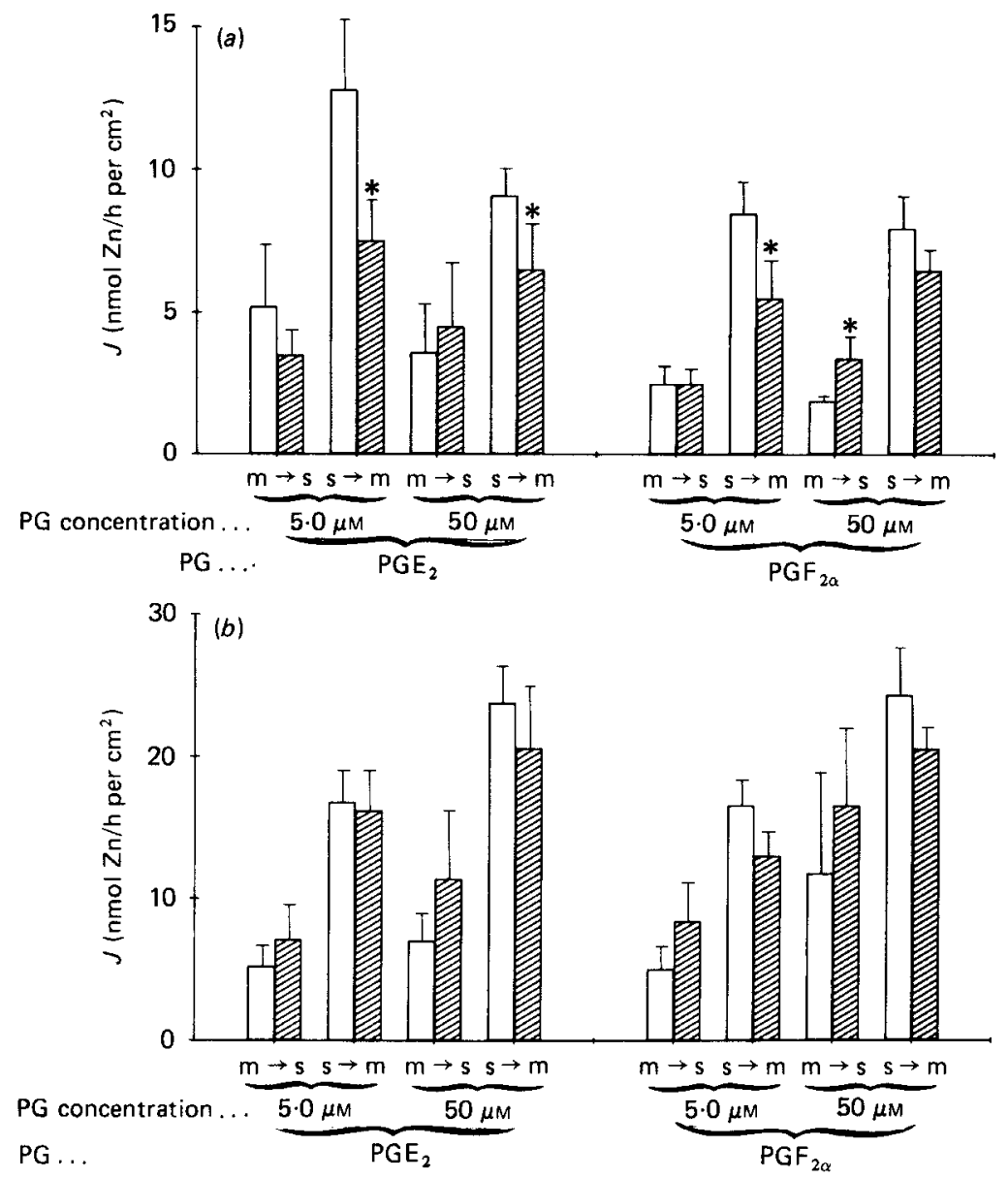

Fig. 1. Effects of prostaglandins (PGs) on the zinc flux rate $(J)$ across isolated rat jejunal segments. $(a)$ $J$ when PG was added on the mucosal side of the segment during the measurement of ${ }^{65} \mathrm{Zn}$ flux rate from mucosa $(\mathrm{m})$ to serosa $(\mathrm{s})\left(J_{\mathrm{ms}}\right)$, and the serosal side during the measurement of ${ }^{65} \mathrm{Zn}$ flux rate from serosa to mucosa $\left(J_{\mathrm{sm}}\right)$; (b) $J$ when PG was added on the serosal side of the segment during the measurement of $J_{\mathrm{ms}}$ and to the mucosal side during the measurement of $J_{\mathrm{sm}}$. Student's $t$ test was used to compare experimental and control means. The columns represent the means, with their standard errors represented by vertical bars, for six determinations. $\square$, Control; 國, PG added; * $P<0.05$.

enhanced while with 5.0 and $50 \mu \mathrm{M}-\mathrm{PGE}_{2}$ and $5.0 \mu \mathrm{M}-\mathrm{PGF}_{2 \alpha}$ there was no significant effect on $J_{\mathrm{ms}}$. The $J_{\mathrm{sm}}$ was always greater than $J_{\mathrm{ms}}$ under short-circuit current conditions. The addition of $\mathrm{PGs}$, regardless of type or amount of $\mathrm{PG}$ added, decreased net ${ }^{65} \mathrm{Zn}$ secretion and, except in the case of $5 \cdot 0 \mu \mathrm{M}-\mathrm{PGE}_{2}$, the decrease was significant (Table 1).

\section{The ${ }^{65} \mathrm{Zn}$ flux rate when $P G$ was added to the intestinal-segment-bathing buffer solution containing only non-radioactive $\mathrm{Zn}$}

To determine whether chelation of $\mathrm{Zn}$ by PGs is an essential step for $\mathrm{Zn}$ flux across the intestinal segment, PGs were added to the non ${ }^{65} \mathrm{Zn}$ containing (cold) side of the intestinal segment. Although PGs did not significantly stimulate $J_{\mathrm{ms}}$ or inhibit $J_{\mathrm{sm}}$ (Fig. $1 b$ ), decrement of net Zn secretion was significant except for $5.0 \mu \mathrm{M}-\mathrm{PGE}_{2}$. In these experiments, 
Effect of prostaglandins on zinc transport

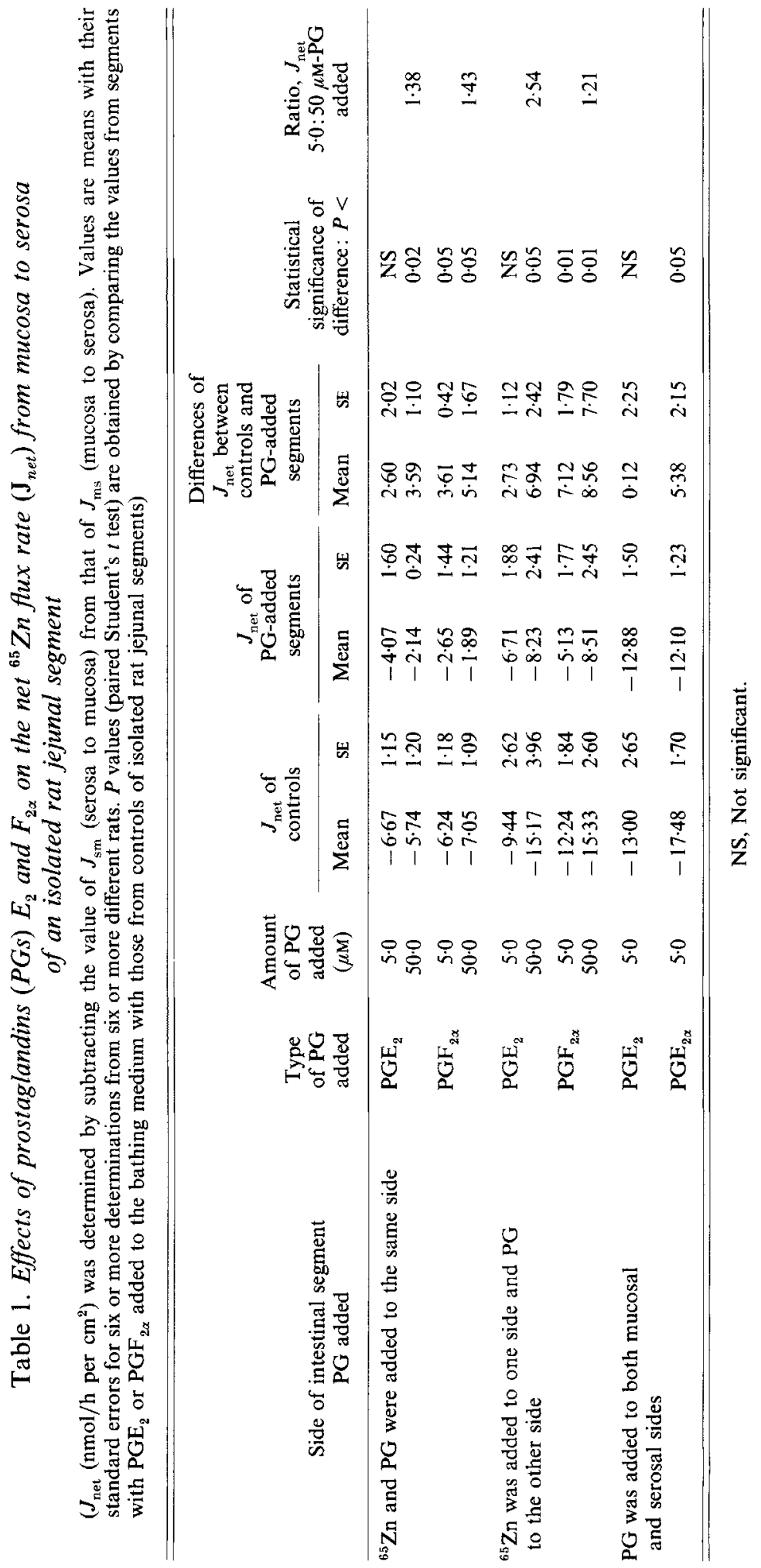




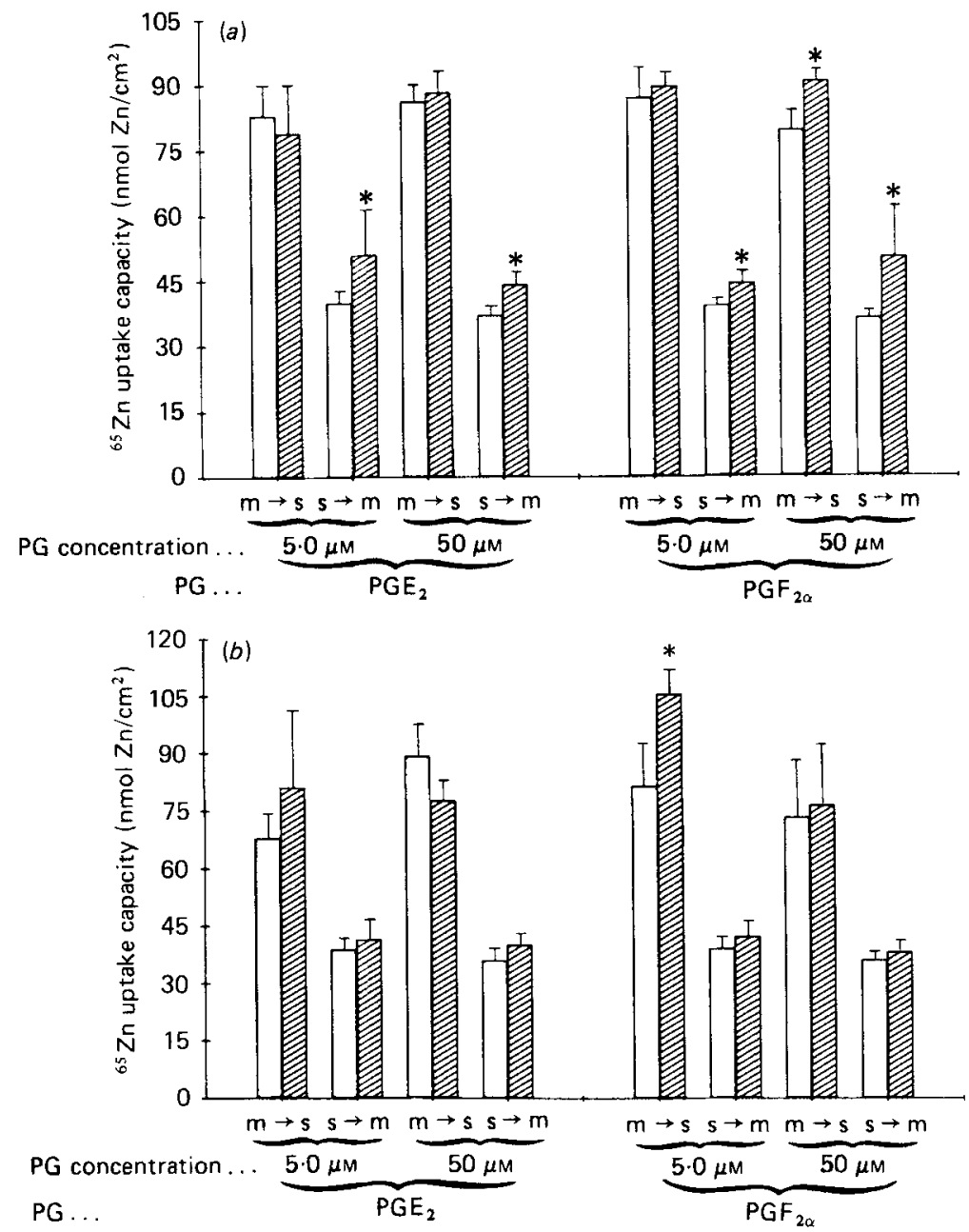

Fig. 2. Effect of prostaglandins (PGs) on ${ }^{65} \mathrm{Zn}$ uptake capacity of rat jejunal segments. At the end of the experiments described in Fig. $1,{ }^{65} \mathrm{Zn}$ contents of all jejunal tissues were counted and the results analysed for statistical significances using Student's $t$ test. Columns represent the means, with their standard errors represented by vertical bars, for six determinations. $\square$, Control; 圈, PG added; ${ }^{*} P<0 \cdot 05$.

the $J_{\mathrm{ms}}$ of controls was $7.23(\mathrm{SE} 1.09) \mathrm{nmol} / \mathrm{h}$ per $\mathrm{cm}^{2}\left(n\right.$ 24) and $J_{\mathrm{sm}}$ was 20.47 (SE 2.15) $\mathrm{nmol} / \mathrm{h}$ per $\mathrm{cm}^{2}(n 24)$.

\section{Effects of PGs on ${ }^{65} \mathrm{Zn-retaining} \mathrm{capacity} \mathrm{of} \mathrm{intestinal} \mathrm{segments}$}

${ }^{65} \mathrm{Zn}$ contents of intestinal segments were increased after bathing for $2 \mathrm{~h}$ with $0.5 \mathrm{~mm}-\mathrm{Zn}$ plus ${ }^{65} \mathrm{Zn}$ on one side, and only $0.5 \mathrm{~mm}$-non-radioactive $\mathrm{Zn}$ on the other side. Addition of PGs and ${ }^{65} \mathrm{Zn}$ to the serosal side of intestinal segments significantly increased the ${ }^{65} \mathrm{Zn}$ content of tissues regardless of type of PG or amount (Fig. $2 a$ ). However, only $50 \mu \mathrm{M}-$ $\mathrm{PGF}_{2 \alpha}$ added to the mucosal side together with ${ }^{65} \mathrm{Zn}$ significantly increased the ${ }^{65} \mathrm{Zn}$ content of tissues compared with controls. When PGs were added to the serosal side of intestinal segments and ${ }^{65} \mathrm{Zn}$ was added to the mucosal side of the segments, only $5 \cdot 0 \mu \mathrm{M}-\mathrm{PGF}_{2 \alpha}$ 

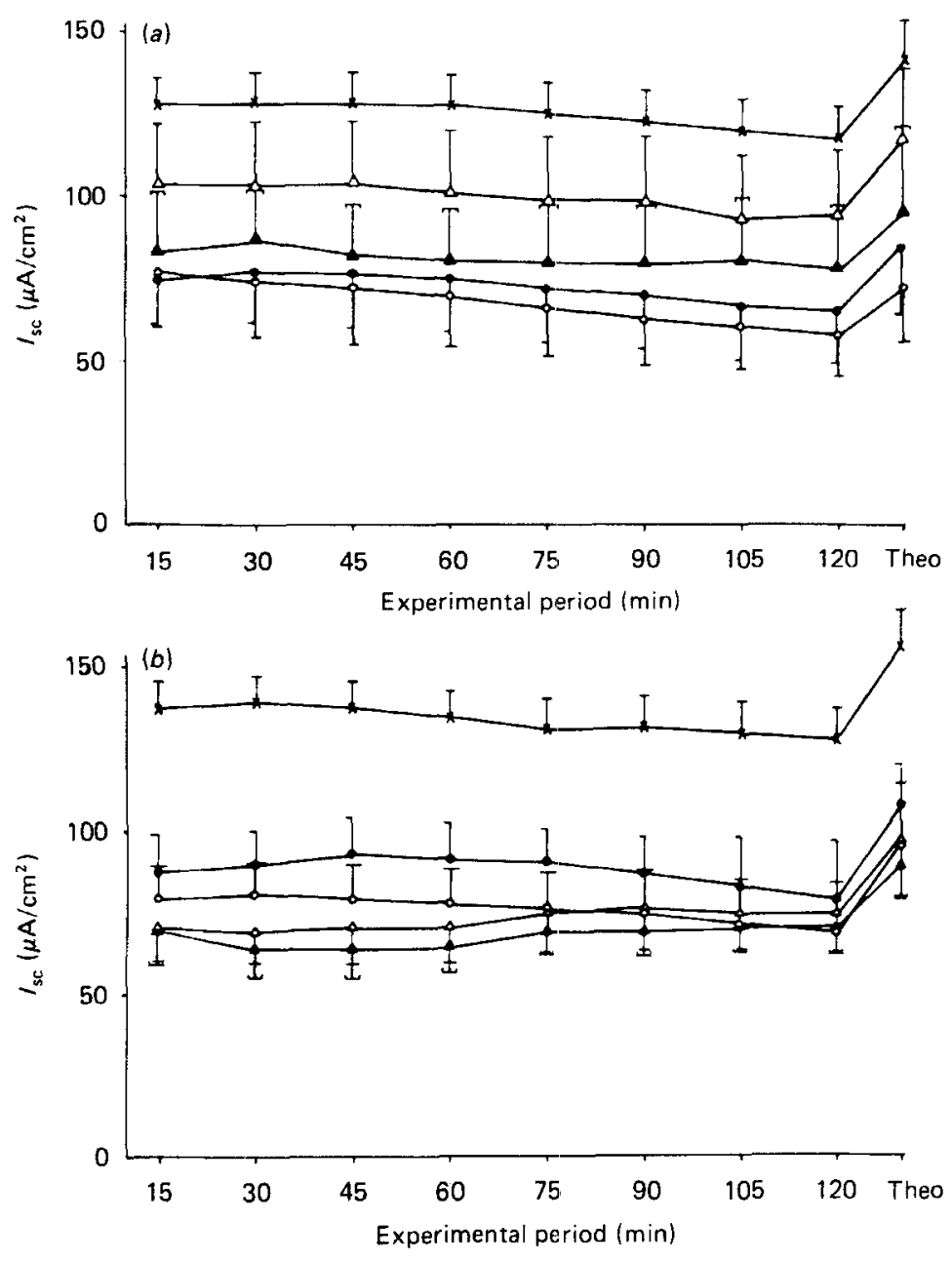

Fig. 3. Effect of prostaglandins (PGs) on the base-line short-circuit current $\left(I_{\mathrm{se}}\right)$ between the media bathing both sides of the jejunal segments. The experimental conditions are as described in Fig. $1 . I_{\mathrm{sc}}$ was read every 15 min during the $2 \mathrm{~h}$ period of the experiment at the time of sampling to measure ${ }^{65} \mathrm{Zn}$ flux rate. Points are means, with their standard errors represented by vertical bars, for six determinations. (a), $\mathrm{PGE}_{2} ;(b) \mathrm{PGF}_{2 \alpha} ; x$, control; $\mathrm{O}, 5 \mu \mathrm{M}-\mathrm{PG}$ to mucosa;, $50 \mu \mathrm{M}-\mathrm{PG}$ to mucosa; $\triangle, 5 \mu \mathrm{M}-\mathrm{PG}$ to serosa; A, $50 \mu \mathrm{M}-\mathrm{PG}$ to serosa. Theo, theophylline.

significantly increased the ${ }^{65} \mathrm{Zn}$ content of tissues compared with controls (Fig. $2 b$ ). When PGs were added to the mucosal side of tissue and ${ }^{65} \mathrm{Zn}$ was added to the serosal side, no effect of PG on the ${ }^{65} \mathrm{Zn}$ uptake capacity of tissues was observed.

\section{Electrical variables of the jejunal segments}

The effects of $\mathrm{PGE}_{2}$ and $\mathrm{PGF}_{2 \alpha}$ on the electrical variables of jejunal segments were determined (Figs 3-5). Addition of PGs, regardless of amount, type of PG and the side of jejunal segment, significantly decreased $I_{\mathrm{sc}}$ and PD compared with controls. Although $I_{\mathrm{sc}}$ and PD increased initially for a few minutes, all their values at $15 \mathrm{~min}$ incubation were lower than those of controls. When $\mathrm{PGE}_{2}$ was added to the mucosal side of a jejunal 

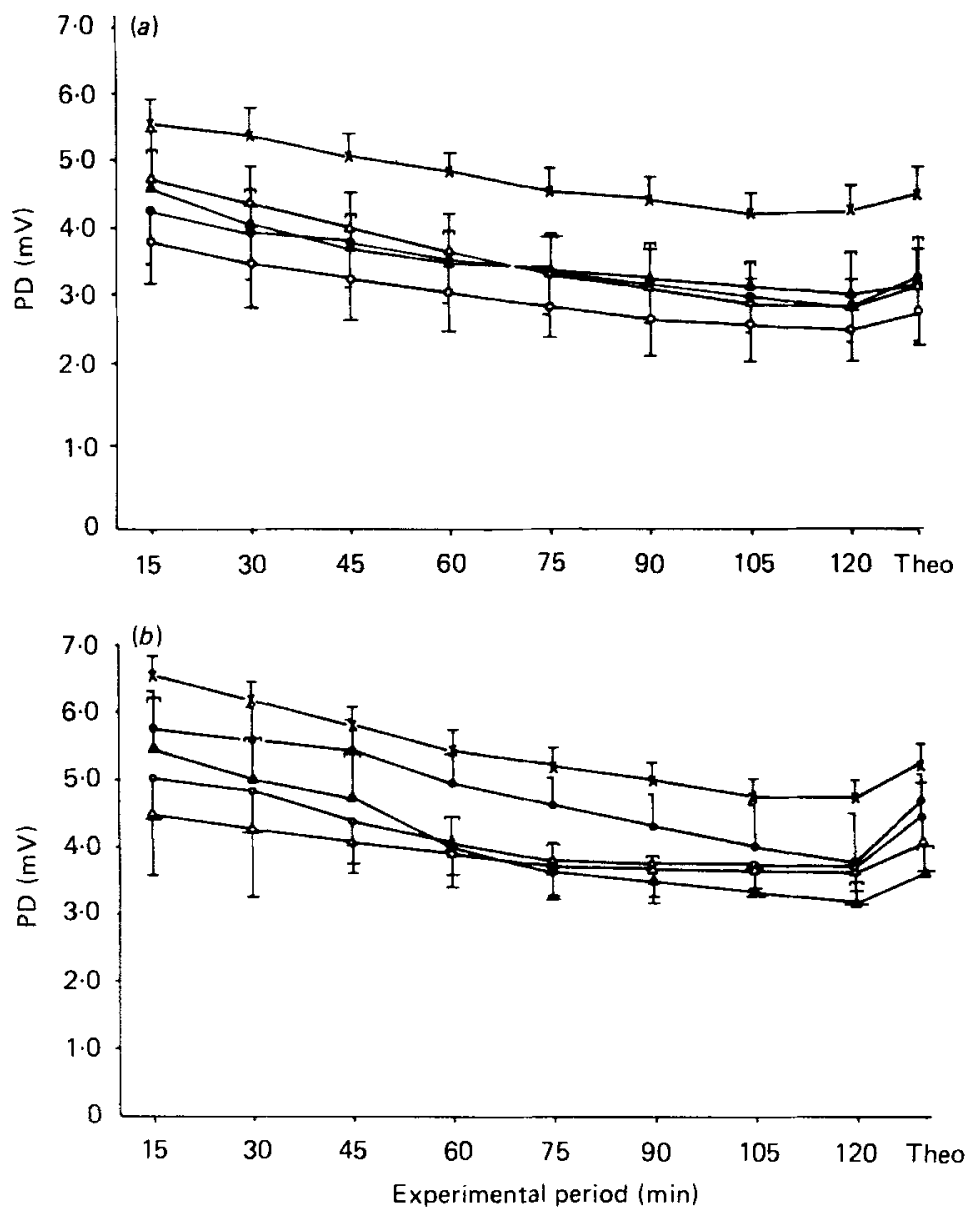

Fig. 4. Effects of prostaglandins on the potential difference (PD) between the media bathing both sides of the jejunal segments. The experimental conditions are as described in Fig. 1. PD was calculated from the current required for the voltage clamp to produce an increase of $10 \mathrm{mV}$. Points are the means, with their standard errors represented by vertical bars, for six determinations. $(a), \mathrm{PGE}_{2} ;(b), \mathrm{PGF}_{2 \alpha} ; \times$, controi; $\mathrm{O}, 5 \mu \mathrm{M}-\mathrm{PG}$ to mucosa;, $50 \mu \mathrm{M}-\mathrm{PG}$ to mucosa; $\triangle, 5 \cdot 0 \mu \mathrm{M}-\mathrm{PG}$ to serosa; $\Delta, 50 \mu \mathrm{M}-\mathrm{PG}$ to serosa. Theo, theophylline.

segment, $I_{\mathrm{sc}}$ was lower than when it was added to the serosal side of the segment (Fig. $3 a$ ). In contrast, when $\mathrm{PGF}_{2 \alpha}$ was added to the serosal side of the jejunal segment, $I_{\mathrm{sc}}$ was more drastically reduced than when $\mathrm{PGF}_{2 \alpha}$ was added to the mucosal side of the segment. However, no specific difference between $5.0 \mu \mathrm{M}$ and $50 \mu \mathrm{M}$ was observed in the effect on $I_{\mathrm{sc}}$. At the end of each experiment, theophylline was added to the buffer solutions bathing both mucosal and serosal sides of jejunal segments. An increase in both $I_{\mathrm{sc}}$ and PD was an indication of viable tissue (Lee, 1983).

Like $I_{\mathrm{sc}}$, PD was also depressed when PG was added to the tissue-bathing medium. When $50 \mu \mathrm{M}$-PGs were added to the jejunum-bathing media, the values of PD were generally higher than those when $5.0 \mu \mathrm{M}$-PGs were added. The findings also suggest that PGE $_{2}$ was more effective in reducing PD when it was added to the mucosal side of the segment than when it was added to the serosal side (Fig. $4 a$ ). In contrast, PGF $_{2 \alpha}$ was more effective in 


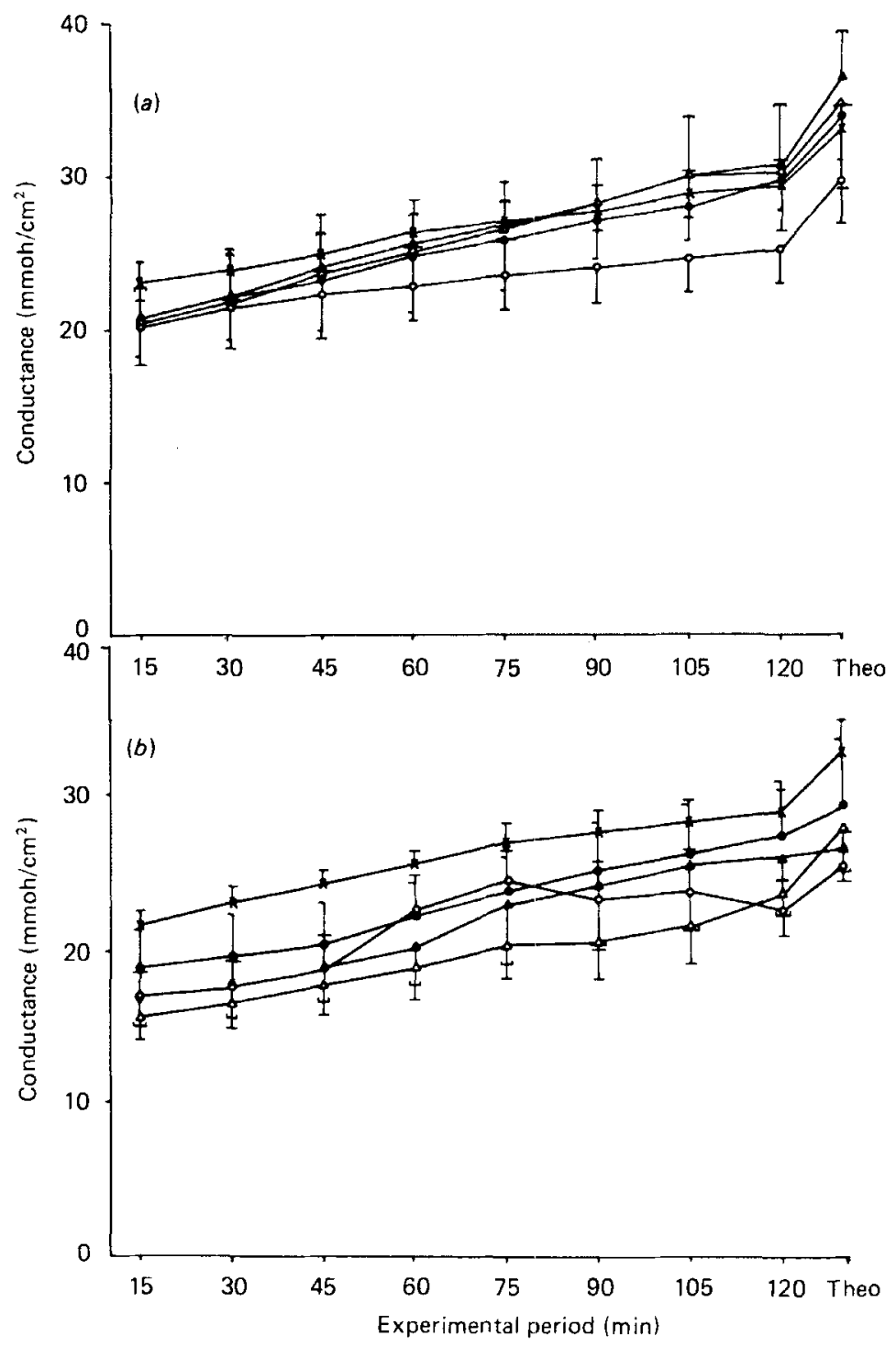

Fig. 5. Effects of prostaglandins on the conductance between the media bathing both sides of the jejunal segment. The experimental conditions are as described in Fig. 1. Resistance was calculated from the values of current and potential difference. Points are means, with their standard errors represented by vertical bars, for six determinations. (a) $\mathrm{PGE}_{2} ;(b) \mathrm{PGF}_{2 \alpha} ; \times$, control; $0,5.0 \mu \mathrm{M}-\mathrm{PG}$ to mucosa; $50 \mu \mathrm{M}-\mathrm{PG}$ to mucosa; $\triangle, 5 \cdot 0 \mu \mathrm{M}-\mathrm{PG}$ to serosa; $\Delta, 50 \mu \mathrm{M}-\mathrm{PG}$ to serosa. Theo, theophylline.

reducing PD when it was added to the serosal side of jejunal segments than when it was added to the mucosal side (Fig. $4 b$ ). In general, the conductance of tissue decreased when PG was added to the medium bathing the jejunal segment. When $5.0 \mu \mathrm{M}-\mathrm{PGE}_{2}$ was added to the mucosal side of the segment, conductance was reduced (Fig. 5a), whereas when it was added to the serosal side, it did not change. However, when $\mathrm{PGF}_{2 \alpha}$ was added to the jejunum-bathing medium, conductance invariably decreased (Fig. $5 b$ ). 


\section{DISCUSSION}

The work reported here is a study of the effects of physiological and pharmacological doses of PGs on $\mathrm{Zn}$ flux across mammalian jejunum mounted in an Ussing chamber. Viability of tissue was assessed by measuring its electrical variables and its response to theophylline. If tissues are damaged or not viable, there will be an open circuit across the epithelium.

Two models have been presented to account for the regulation of the $\mathrm{Zn}$ transport mechanism. One hypothesis states that the increase in permeability of $\mathrm{Zn}$ across the small intestine is due to chelation by LMW-ZBL which then carries $\mathrm{Zn}$ across mucosal cells (Cousins et al. 1978; Hurley et al. 1977 a; Evans \& Johnson, 1980; Lonnerdal et al. 1980; Wapnir et al. 1983). Wapnir et al. (1983) reported that L-histidine is able to chelate $\mathrm{Zn}$ and stimulate intestinal $\mathrm{Zn}$ transport. In preliminary experiments, we determined that $\mathrm{L}^{-}$ histidine increases lumen $\mathrm{Zn}$ availability for absorption. The other model is a hormonal effect which controls Zn metabolism (Etzel et al. 1979; Castro-Magana et al. 1981; Latman et al. 1984) by an unknown mechanism.

Our findings (Fig. 1 and Table 1) lead us to conclude that PGs influence the intestinal $\mathrm{Zn}$ transport rate by acting as hormone-like substances rather than as chelating agents, for two reasons. First, PGs added to the side of the intestinal segment opposite to the side to which ${ }^{65} \mathrm{Zn}$ was added showed an effect on the $\mathrm{Zn}$ flux rate which was similar to that obtained when it was added to the same side. It would be expected that only PGs added to the side to which ${ }^{65} \mathrm{Zn}$ was added would show the change of ${ }^{65} \mathrm{Zn}$ flux rate across the intestinal segment if chelation of $\mathrm{Zn}$ by $\mathrm{PG}$ is required. However, the $\mathrm{Zn}$ flux rate did not change significantly when PG was added to either the mucosal or serosal sides when $J_{\mathrm{ms}}$ or $J_{\mathrm{sm}}$ was measured. Second, the findings did not show any significant difference between low dose $(5.0 \mu \mathrm{M})$ and high dose $(50 \mu \mathrm{M})$ treatment of the intestinal segment. If chelation of $\mathrm{Zn}$ is required, a tenfold increase in PGs should produce an observable difference in the Zn flux rate. However, no difference in the $\mathrm{Zn}$ flux rate was observed after increasing the PG concentration tenfold. Thus no evidence of an essential role of $\mathrm{Zn}$ chelation by PGs in regulating intestinal $\mathrm{Zn}$ transport appears from the present findings. However, the findings do suggest that PGs have a transducing activity capable of stimulating or inhibiting Zn flux rate.

Addition of PGs to the buffer solutions bathing the serosal side of the jejunal segments generally decreased $J_{\mathrm{sm}}$ and increased $J_{\mathrm{ms}}$ regardless of amount or type of PGs (Fig. 1). However, tissue ${ }^{65} \mathrm{Zn}$ uptake capacity increased when $\mathrm{PG}$ was added to the serosal side of the jejunum but when PG was added to the mucosal side only $50 \mu \mathrm{M}-\mathrm{PGF}_{2 \alpha}$ added to the same side as the ${ }^{65} \mathrm{Zn}$ made any difference, producing an increase in uptake (Fig. 2). These findings are somewhat reminiscent of the fact that metallothionein induction in the intestinal mucosal cells inhibits $\mathrm{Zn}$ absorption, even though metallothionein increases ${ }^{65} \mathrm{Zn}$ uptake of intestinal mucosal cells (Song et al. 1984).

Since PGs participate in controlling protein synthesis by interacting with cAMP (Singhal et al. 1976), it is expected that PGs added to the serosal side of intestinal segments may stimulate synthesis of proteins such as metallothionein and thereby increase accumulation of $\mathrm{Zn}$ in the cytosol. The fact that a high dose of $\mathrm{PGF}_{2 \alpha}$ increased both $J_{\mathrm{ms}}$ and tissue ${ }^{65} \mathrm{Zn}$ uptake (Figs 1 and 2 ) is consistent with the fact that $\mathrm{PGF}_{2 \alpha}$ increased $\mathrm{Zn}$ binding activity of metallothionein (Song et al. 1985). Thus, it is possible that $\mathrm{PGF}_{2 \alpha}$ may stimulate $\mathrm{Zn}$ absorption by triggering the synthesis of a protein which binds $\mathrm{Zn}$ and carries it across the small intestine and that PGs only on the serosal side are effective in controlling intestinal $\mathrm{Zn}$ transport. However, this possibility should be examined in further detailed experiments.

$I_{\mathrm{sc}}$ was invariably depressed by the addition of PGs to the jejunal-segment-bathing 
medium (Fig. 3). $I_{\mathrm{sc}}$ was measured to show that the isolated jejunal segments of rats were viable and to keep $I_{\mathrm{sc}}$ equalized under a variety of experimental conditions (Mendoza, 1973). $\mathrm{PGE}_{2}$ inhibits $\mathrm{NaCl}$ transport in single, thick, ascending loops of Henle in the mouse kidney (Culpepper \& Andreoli, 1983). Therefore, it may be that sodium transport in rat small intestine is inhibited by PGs and that possibly $\mathrm{Zn}$ transport is also inhibited. At the same time, it has been shown that depression of $I_{\mathrm{sc}}$ and PD is usually a reflection of inhibition of active anion secretion (Mendoza, 1973).

Since more than $85 \%$ of the transmural conductance is attributable to the extracellular shunt pathway (Frizzell \& Schultz, 1972), depression of conductance by PGs could account for the change in ionic diffusion (simple diffusion). However, $\mathrm{PGE}_{2}$ added to the serosal side of jejunal segments did not alter transmural conductance (Fig. 5). Therefore, it appears that the $\mathrm{Zn}$ transport process under the present experimental conditions occurred mainly through intracellular handling of $\mathrm{Zn}$ by mucosal cells, since the transport across the mucosal membrane of the epithelial cells is not significantly affected by small changes in PD and, according to Frizzell \& Schultz (1972), the movement through the extracellular pathway is directly influenced by an imposed transepithelial electrical field.

Administration of either $\mathrm{PGE}_{2}$ or $\mathrm{PGF}_{2 \alpha}$ in the small intestine of human subjects via oral, intraperitoneal or parenteral routes elicits fluid and electrolyte secretion (Rask-Madsen, 1986). Thus, some effect of PGs on the fluid movement in our experimental conditions is to be expected. If the water movement is significant, $\mathrm{Zn}$ might be transported by the effect of 'solvent drag'. However, the amount of change which could be expected on the net fluid movement is too small to be observed under our experimental conditions. Furthermore, PGs do not affect L-histidine transport rate across rat small intestine although PGs control $\mathrm{Zn}$ transport rate (Song \& Adham, 1979). Therefore, the effect of PGs on the Zn transport process appears not to depend on the fluid movement. However, detailed studies correlating $\mathrm{Zn}$ transport with water movement might reveal the possible effect of fluid movement on the $\mathrm{Zn}$ transport process.

In summary, these findings suggest that chelation of $\mathrm{Zn}$ by $\mathrm{PGs}$ in the intestinal lumen may not be important for regulation of the $\mathrm{Zn}$ transport process across the mucosal cells of the jejunum, that only the serosal PGs are effective in the control of $\mathrm{Zn}$ transport and $\mathrm{Zn}$ uptake capacities of intestinal segments, and that the Ussing chamber method is a useful technique for studying epithelial $\mathrm{Zn}$ transport in vitro in the absence of electrical gradients.

The authors thank Messrs Cecil Carmack, Vincent Sile and Micha B. Beck for their skilful technical assistance. They also thank Dr Herman Schott for valuable suggestions.

This work was supported by the Medical Research Service of the Veterans Administration of the United States.

\section{REFERENCES}

Biber, T. U. L., DeSimone, J. A. \& Drewnoska, K. (1986). Biochimica et Biophysica Acta 862, 27-38.

Castro-Magana, M., Collipp, P. J., Chen, S. Y., Cheruvanky, T. \& Maddaiah, V. T. (1981). American Journal of Diseases of Children 135, 322-325.

Cousins, R. J. (1979a). Nutrition Reviews 37, 97-103.

Cousins, R. J. (1979 b). American Journal of Clinical Nutrition 32, 339-345.

Cousins, R. J., Smith, K. T., Failla, M. L. \& Markowitz, L. A. (1978). Life Sciences 23, 1819-1826.

Culpepper, R. M. \& Andreoli, T. E. (1983). Journal of Clinical Investigation 71, 1588-1601.

Cunnane, S. C. (1982). Pediatric Research 16, 559-603.

Etzel, K. R., Shapiro, S. G. \& Cousins, R. J. (1979). Biochemical and Biophysical Research Communications 89, $1120-1126$.

Evans, G. W., Grace, C. I. \& Vetava, H. J. (1975). American Journal of Physiology 228, 501-505.

Evans, G. W. \& Johnson, P. E. (1980). Pediatric Research 14, 876-880. 
Frizzell, R. A. \& Schultz, S. G. (1972). Journal of General Physiology 59, 318-346.

Hamberg, M. \& Samuelsson, B. (1971). Journal of Biological Chemistry 246, 6713-6721.

Hurley, L. S., Lonnerdal, B. \& Stanislowski, A. G. (1977a). Lancet i, 677.

Hurley, L. S., Sloan, M. V., Duncan, J. F. \& Eckhert, C. D. (1977 b). Proceedings of the National Academy of Sciences, USA 74, 3547-3549.

Latman, N. S., Sorensen, J. R. J. \& Kishore, V. (1984). Hormone Research 20, 192-196.

Lee, D. B. N. (1983). Journal of Clinical Investigation 71, 322-328.

Lonnerdal, B., Schneeman, B. O., Keen, C. I. \& Hurley, L. S. (1980). Journal of Inorganic Biochemistry 12, 71-78.

Menard, M. P. \& Cousins, R. J. (1983). Journal of Nutrition 113, $1434-1442$.

Mendoza, S. A. (1973). American Journal of Physiology 225, 476-480.

Pearson, W. N., Schwink, T. \& Reich, M. (1966). In Zinc Metabolism, pp. 239-249 [A. S. Prasad, editor]. Springfield, Hlinois: Charles C. Thomas.

Rask-Madsen, J. (1986). Clinics in Gastroenterology 15, 545-566.

Singhal, R. L., Tsang, B. K. \& Sutherland, D. J. B. (1976). In Cellular Mechanisms Modulating Gonadal Hormone Action, pp. 325-424 [R. L. Singhal and J. A. Thomas, editors]. Baltimore: University Park Press.

Song, M. K. \& Adham, N. F. (1978). American Journal of Physiology 234, E99-E105.

Song, M. K. \& Adham, N. F. (1979). Journal of Nutrition 109, 2152-2159.

Song, M. K., Adham, N. F. \& Ament, M. E. (1984). Biological Trace Element Research 6, 181-193.

Song, M. K., Adham, N. F. \& Ament, M. E. (1985). Nutrition Reports International 32, 71-82.

Ussing, H. H. \& Zerahn, K. (1951). Acta Physiologica Scandinavica 23, 110-119.

Wapnir, R. A., Khani, D. E., Bayne, M. A. \& Lifshitz, A. J. (1983). Journal of Nutrition 113, $1346-1354$. 